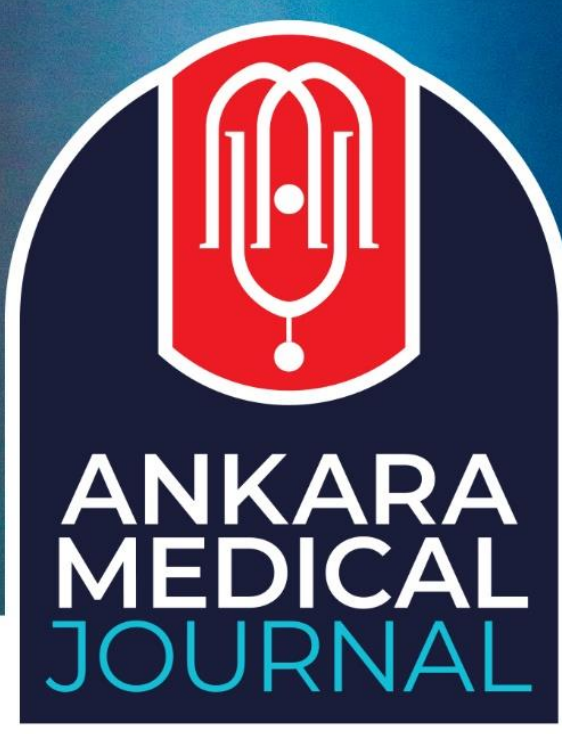

Research Article

Ankara Med J, 2021;(1):57-71 // 10.5505/amj.2021.57767

\title{
EVALUATION OF RISK FACTORS FOR CARDIOVASCULAR DISEASES AND PREVALENCE OF METABOLIC SYNDROME IN OVERWEIGHT AND OBESE ADOLESCENTS
}

\section{FAZLA KİLOLU VE OBEZ ADÖLESANLARDA METABOLİK SENDROM SIKLIĞI İLE KARDIYYOVASKÜLER RİSK FAKTÖRLERİNIN DEĞERLENDİRİLMESİ}

(D) Yağmur Gökseven1, (D) Guzin Zeren Ozturk²

${ }^{1}$ Hassa State Hospital, Family Medicine, Hatay

${ }^{2}$ Health Sciences University, Sisli Hamidiye Etfal Training and Research Hospital, Family Medicine Clinics, Istanbul

Yazışma Adresi / Correspondence:

Uzm. Dr. Yağmur Gökseven (e-mail: yagmurgokseven@hotmail.com)

Geliş Tarihi (Submitted): 13.12.2020 // Kabul Tarihi (Accepted): 17.02.2021

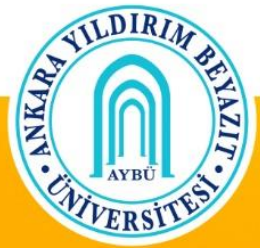

Ankara Yıldirım Beyazit University Faculty of Medicine Department of Family Medicine 


\title{
Öz
}

Amaç: 5-19 yaş arası 340 milyonun üzerinde fazla kilolu veya obez olduğu bildirilmiştir. Çocukluk çağı ve adölesan dönemde başlayan obezite, metabolik sendrom ve kardiyovasküler hastalıklara zemin hazırlamakta, aterosklerotik sürecin hızlanmasına neden olmaktadır. Çalışmamızın amacı aşırı kilolu ve obez adölesanlarda kardiyovasküler hastalıklar için risk faktörlerini ve metabolik sendrom sıklığını değerlendirmektir.

Materyal ve Metot: Çalışma popülasyonu 11-18 yaş arası fazla kilolu ve obez adölesanlardan oluşmaktadır. Katılımcıların antropometrik ölçümleri ve kan örneklerini aldıktan sonra REGODCI puanlama sistemine göre kardiyovasküler riskleri ve Uluslararası Diyabet Federasyonu'na göre metabolik sendrom prevalansları incelenmiștir.

Bulgular: Çalışmaya 150 fazla kilolu ve obez adölesan dahil edildi. Katılımcıların 115 'i $(\% 76,70)$ obez idi; \%22'sinde ( $\mathrm{n=33)}$ Metabolik sendrom (MetS); \%46,60'ında ( $\mathrm{n=80)}$ kardiyometabolik risk (KMR) varlığı saptandı. MetS tanısı alan katılımcıların vücut kitle indeksleri (VKI), sistolik kan basıncı, TG-HDL oranları arasında istatistiksel olarak anlamlı fark saptandı (sırasıyla $p=0,040, p=0,012$ ve $p<0,001$ ). KMR varlığı ile katılımcıların VKİ, TG-HDL oranları, bel- kalça çevresi oranları arasında istatiksel anlamlı bir ilişki saptandı (sırasıyla $p=0,001, p=0,001$ ve $p=0,034$ ). ROC analizine göre MetS için eğri altındaki alan 0,826, kesme değeri 2,59; \%72 duyarlılık ve \%72 özgüllük ile bulundu; KMR varlığı için eğri altında kalan alan 0,652; kesim değeri 2,06; \%65 duyarlılık ve \%63 özgüllük ile bulundu.

Sonuç: Obezite hem MetS hem de KMR için bağımsız bir risk faktörüdür ve tanıdan hemen sonra tedavi edilmelidir. Fazla kilolu ve obez adölesanlarda TG/HDL oranı MetS (2,59 üzeri) ve CMR (2,06 üzeri) için prediktör faktör olarak kullanılabilir.

Anahtar Kelimeler: Adölesan, kardiyometabolik risk, metabolik sendrom, obezite.

\begin{abstract}
Objectives: It is reported that there are more than 340 million people who are either overweight or obese aged between 5-19. Obesity starting in childhood and adolescence leads up to metabolic syndrome, cardiovascular diseases and hastens the atherosclerotic process. The aim of our study is to evaluate risk factors for cardiovascular diseases and the prevalence of metabolic syndrome in overweight and obese adolescents.

Materials and Methods: The study population comprised overweight and obese adolescents aged 11-18 years. After taking all anthropometric measurements and blood samples; cardiovascular risk according to the REGODCI scoring system and prevalence of metabolic syndrome according to the International Diabetes Federation were examined.

Results: 150 overweight and obese adolescents were included. 115 (76.70\%) subjects were determined as obese. MetS was seen in 22\% ( $n=33)$; cardiometabolic risk (CMR) was seen in $46.60 \%(n=80)$ of the participants. A statistically significant difference between systolic blood pressure, TG/HDL, and BMI of participants diagnosed with MetS was detected $(\mathrm{p}=0.040, \mathrm{p}=0.012, \mathrm{p}<0.001$, respectively). A significant correlation was found between CMR and participants' BMI, TG/HDL, waist-hip ratio $(\mathrm{p}=0.001, \mathrm{p}=0.001, \mathrm{p}=$ 0.034, respectively). According to the ROC analysis for MetS, the area under the curve was 0.826 , the cutoff value was 2.59 with $72 \%$ sensitivity and $72 \%$ specificity; and for the CMR the area under the curve was 0.652 , the cutoff value was 2.06 with $65 \%$ sensitivity and $63 \%$ specificity.

Conclusion: Obesity is an independent risk factor for both MetS and CMR, and it should be treated immediately after diagnosis. TG/HDL ratio may use as a predictor factor for MetS (over 2.59) and for CMR (over 2.06) in overweight and obese adolescents.

Keywords: Adolescent, cardiometabolic risks, metabolic syndrome, obesity.
\end{abstract}




\section{Introduction}

The prevalence of obesity has been rapidly increasing worldwide, and obesity has now become one of the most common chronic health problems in children. According to World Health Organization (WHO), 40 million children ages $<5$ years and 340 million children and adolescents aged 5-19 years are either overweight or obese. ${ }^{1}$ Metabolic syndrome (MetS) is described as a fatal endocrinopathy, which manifests with insulin resistance and involves systemic disorders such as abdominal obesity, dyslipidemia, hypertension, coronary artery diseases, glucose intolerance, or diabetes mellitus (DM). ${ }^{2}$ Moreover, obesity in children and adolescents may lead to cardiovascular diseases and accelerate the atherosclerotic process. In the light of the data collected to date, atherosclerotic heart disease becomes a lifelong risk with the addition of modifiable factors such as obesity, hypertension, and dyslipidemia, particularly in children who have a genetic predisposition to atherosclerotic heart disease. ${ }^{3}$

The present study aimed to evaluate the risk factors for cardiovascular diseases and the prevalence of MetS in overweight and obese adolescents.

\section{Materials and Methods}

\section{Study population}

This study is a single-center and cross-sectional study. The study population comprised overweight (BMI at or above the $85^{\text {th }}$ percentile) and obese (BMI above the $95^{\text {th }}$ percentile) adolescents and those who had aged 11-18 years, who presented at the outpatient clinics of the Family Medicine Clinic of Şişli Hamidiye Etfal Training and Research Hospital between 01.05.2018 and 01.08.2018. ${ }^{4}$ Subjects who had a known chronic disease and a mental or physical disability and those who were using drugs affecting body weight were excluded. First, the results of anthropometric measurements and blood samples were evaluated. Then, the prevalence of cardiovascular risk score (CMR) according to the REGODCI scoring system and metabolic syndrome (MetS) prevalence according to the International Diabetes Federation were evaluated.

\section{Anthropometric and clinical measurements}

Waist circumference was measured by passing the meter through the midpoint of the distance between the anterior and superior iliac spine and the costal arch. Hip circumference was measured over the greater trochanter and expressed in centimeters $(\mathrm{cm})$. 
Waist-to-hip ratios were recorded. We were used in evaluating the waist circumference percentiles identified by Hatipoğlu. ${ }^{5}$

Values that were identified in 2004 by the National High BP Education Program Working Group based on age, sex, and height percentiles for children and adolescents were used as a reference. BP measurements were performed using an aneroid sphygmomanometer (ERKA) with a suitable cuff. The measurements were repeated at least twice with at least 5-minute intervals for subjects who were identified as prehypertensive or stage 1 or stage 2 hypertensive according to age, sex, and height percentiles. ${ }^{6}$

\section{Blood samples}

Venous blood samples were collected from the subjects included in the study group in the morning following a minimum of 10 hours of overnight fasting. Biochemical tests were performed on the fasting blood samples using the calorimetric method with a Roche-Hitachi Modular P800 autoanalyzer. Fasting blood glucose (FBG), glycosylated hemoglobin (HbA1c), Triglyceride (TG), low-density lipoprotein (LDL), high-density lipoprotein (HDL), total cholesterol (TC), alanine aminotransferase (ALT), aspartate aminotransferase (AST), thyroid-stimulating hormone (TSH), creatinine and hemoglobin values were calculated from blood samples. TG/HDL ratio was calculated for each subject, and the MetS-CMR relationship, cutoff value, sensitivity, and specificity were determined.

\section{Metabolic syndrome and the cardiometabolic risk assessment}

The subjects included in this study were diagnosed with MetS in accordance with the criteria described by the International Diabetes Federation (IDF). ${ }^{7}$

The cardiometabolic risks (CMR) of the subjects were determined according to the REGODCI scoring system, which comprises two stages. ${ }^{8}$ The first stage involves the presence of obesity, type 2 DM, or hypertension (HT) in the mother or father and birth weight of $<2500 \mathrm{~g}$ or $>4000 \mathrm{~g}$, a bodyweight at or above the $95^{\text {th }}$ percentile according to the WHO criteria, and a BP at or above the $95^{\text {th }}$ percentile in the adolescent according to the National High BP Education Program Working Group criteria proposed for children in $2004 .{ }^{6}$ Each criterion was scored 1 point, with a maximum total score of 4 and minimum total score of 0 . Subjects who had a total score of $\geq 2$ points in the first stage of the scoring were eligible for the second stage. The second stage included FBG levels of $\geq 110 \mathrm{mg} / \mathrm{dl}$ and a TG and HDL value at or above the $90^{\text {th }}$ percentile based on age and sex. The lipoprotein percentile table prepared by Lipid Research Clinics for children and adolescents based on age and sex was used to assess the TG and HDL percentiles. ${ }^{9}$ In the second stage, each criterion was scored 1 point, with a maximum total score of 3 and a minimum total score of 0 . Subjects who had a total score of $\geq 3$ were considered to have CMR. 


\section{Statistical analyses}

The data were statistically analyzed using SPSS 15.0 for Windows. Descriptive statistics were expressed with numbers and percentages for categorical variables and with mean, standard deviation, minimum, maximum, and median values for numerical variables. Two independent groups were compared using the Student's ttest for normally distributed numerical variables and Mann-Whitney $U$ test for numerical variables that were not normally distributed. Ratios in independent groups were compared using the chi-square analysis. A P value of $<0.05$ (alpha) was considered statistically significant. ROC analyzed were determined to cut off for TG/HDL ratio to MetS and CMR.

\section{Results}

The study included 150 subjects; $50.70 \%(n=76)$ of the subjects were females and $49.30 \%(n=74)$ were males, and the mean age was $13.80 \pm 2.20$ (11-18) years. According to the BP; $88 \%(n=132)$ of the study group were normotensive and $3.30 \%(n=5)$ were prehypertensive, whereas $6 \%(n=9)$ had stage 1 HT and $2.70 \%(n=4)$ had stage 2 HT. There were $18(12 \%)$ subjects who were prehypertensive or who had stage 1 or stage $2 \mathrm{HT}$ according to the BP measurements conducted at the institution. According to BMI classification, 35 subjects (23.30\%) were overweight and 115 (76.70\%) were obese. The comparison of the anthropometric measurements and BP values of obese and overweight subjects were shown in Table 1.

Although the mean age was lower in the obese group (13.50 \pm 2.10 years) than in the overweight group (14.30 \pm 1.90 years), and there was no significant relationship between being overweight or obese and age ( $p$ $=0.052)$. BMI classification according to sex revealed significant differences, whereas $69.70 \%(n=53)$ of the females and $83.80 \%(n=62)$ of the males were obese. The degree of obesity was higher in males than in females $(p=0.042)$. As shown in Table 1, which shows that the mean weight, waist circumference, and hip circumference values were higher in the obese group than in the overweight group and the differences were significant.

All the parameters were in the normal range except the TG value as shown in Table-2. The mean FBG, HbA1c, TG, LDL, AST, ALT, TSH, and hemoglobin levels were higher in the obese whereas the mean HDL and creatinine values were higher in the overweight group but only the ALT values were significantly higher in the obese group.

Overall, 33 (22\%) subjects were diagnosed with MetS. Considering the MetS parameters for all subjects were shown in (Figure 1). 
In this study, $22.60 \%(n=26)$ of the obese adolescents and $20 \%(n=7)$ of the overweight subjects were previously diagnosed with MetS. There was no significant relationship between BMI classification and the presence of MetS ( $p=0.744)$. But as shown in Table-3; there was a significant relationship between the mean BMI values and the presence of MetS $(\mathrm{p}=0.040)$. There was a significant relationship between the presence of MetS and mean weight, BMI, waist circumference, and hip circumference values in subjects diagnosed with MetS ( $p=0.036, p=0.040, p=0.003, p=0.014)$.

There was a significant relationship between the mean systolic BP values measured at the institution and the presence of MetS $(\mathrm{p}=0.012)$. The systolic BP was $6 \mathrm{mmHg}$ higher in subjects diagnosed with MetS than in subjects without MetS. There was no significant relationship between the mean diastolic BP values measured at the institution and the presence of MetS, but the subjects diagnosed with MetS had a higher mean diastolic BP value $(\mathrm{p}=0.082)$. There was a significant relationship between BP percentile classification and the presence of MetS ( $p=0.006)$. It was observed that the prevalence of MetS was higher in the subjects with stage 2 hypertension (75\%) compared to normotensive and stage 1 hypertensive subjects (Figure 2).

There was a significant difference between the mean FBG, HDL, and TG values of the subjects diagnosed with MetS and the presence of MetS ( $p<0.001, p<0.001, p<0.001$, respectively, Table 4). The mean FBG and TG values were significantly higher and the mean HDL value was significantly lower in subjects diagnosed with MetS than in subjects without MetS. There was no significant relationship between the presence of MetS and mean HbA1c, LDL, TC, AST, ALT, TSH, creatinine, and hemoglobin values.

The TG/HDL ratio was calculated for all the subjects, and the mean TG/HDL value was $2.65 \pm 2.37$ (0.3922.66). There was a significant relationship between TG/HDL and MetS $(\mathrm{p}<0.001)$ and a positive correlation between the TG/HDL ratio and prevalence of MetS. According to the ROC analysis, the area under the curve was 0.826 , the cutoff value was $72 \%$, sensitivity was $72 \%$, and specificity was 2.59 (Figure $3 a$ ).

According to the REGODCI scoring of the adolescents included in the study, $46.60 \%$ ( $\mathrm{n}=80$ ) of the adolescents had CMR. Males had CMR mostly but not significant ( $\mathrm{p}=0.144)$. Also, there was no significant relationship between age, height, and mean systolic or diastolic BP values and CMR. The subjects with CMR had higher mean body weight, BMI, waist-to-hip ratio, and waist and hip circumferences significantly ( $\mathrm{p}=$ 0.037, $\mathrm{p}=0.001, \mathrm{p}=0.034, \mathrm{p}=0.002, \mathrm{p}=0.028$, respectively). Overall, $8.60 \%(\mathrm{n}=3)$ of the overweight adolescents and 58.30\% $(n=67)$ of the obese adolescents had CMR. There was no significant difference between CMR and BP percentile classification ( $\mathrm{p}=0.240)$. Overall, 43.90\% $(\mathrm{n}=58)$ of the normotensive group, $80 \%(n=4)$ of the prehypertensive group, $55.60 \%(n=5)$ of the stage 1 hypertension group, and $75 \%$ $(n=3)$ of the stage 2 hypertension group had CMR. 
There was a significant relationship between the reference FBG, HDL, and AST values and the presence of CMR ( $p=0.013, p=0.038, p=0.029$, respectively). Overall, $60 \%(n=33)$ of the subjects with FBG levels of $\geq 100 \mathrm{mg} / \mathrm{dl}$ had CMR, wherein CMR increased with increasing FBG levels. CMR increased with elevated AST levels.

Overall, 80\% ( $\mathrm{n}=8$ ) of the subjects with an AST level of $\geq 35 \mathrm{U} / \mathrm{L}$ had CMR. There was a negative correlation between the HDL level and CMR. The mean HDL, TG, and ALT values had a significant relationship with the presence of CMR ( $p=0.001, p=0.031, p=0.008$, respectively). The mean TG and ALT values were higher but the mean HDL value was lower in the subjects with CMR than in subjects without CMR. There was no significant relationship between the mean FBG, HbA1c, TC, AST, TSH, creatinine, and hemoglobin values and the presence of CMR. The subjects with CMR had higher mean FBG and AST values than the subjects without CMR. There was a significant relationship between the TG/HDL ratio and CMR, wherein the ratio had a positive correlation with the CMR ( $\mathrm{p}=0.001)$. According to the ROC analysis, the area under the curve was 0.652 , the cutoff value was $65 \%$, sensitivity was $63 \%$, and specificity was 2.06 (Figure $3 \mathrm{~b}$ ).

There was a significant relationship between MetS scoring and CMR ( $\mathrm{p}=0.001)$. It was observed that the subjects with CMR had higher MetS scores than did the subjects without CMR.

Table 1. Comparison of the anthropometric measurements and BP values in obese and overweight individuals

\begin{tabular}{|c|c|c|c|c|}
\hline & $\begin{array}{c}\text { Total } \\
n=150\end{array}$ & $\begin{array}{c}\text { Overweight } \\
n=35\end{array}$ & $\begin{array}{c}\text { Obese } \\
n=115 \\
\end{array}$ & \\
\hline & mean $\pm s s$ & mean \pm ss & mean \pm ss & $\mathbf{p}$ \\
\hline Height $(\mathrm{cm})$ & $160.7 \pm 10.5$ & $161.7 \pm 9$ & $160 \pm 10.9$ & 0.343 \\
\hline Weight (kg) & $72.4 \pm 15.3$ & $64.9 \pm 11$ & $74.7 \pm 15.7$ & $<0.001$ \\
\hline BMI $\left(\mathrm{kg} / \mathrm{m}^{2}\right)$ & $27.8 \pm 3.6$ & $24.6 \pm 1.7$ & $28.7 \pm 3.3$ & $<0.001$ \\
\hline Waist circumference $(\mathrm{cm})$ & $91.6 \pm 9.4$ & $86.1 \pm 6.8$ & $93.2 \pm 9.4$ & $<0.001$ \\
\hline Hip circumference $(\mathrm{cm})$ & $104.8 \pm 9.3$ & $99.6 \pm 7.7$ & $106.4 \pm 9.1$ & $<0.001$ \\
\hline Waist-to-hip ratio & $0.87 \pm 0.06$ & $0.86 \pm 0.04$ & $0.87 \pm 0.05$ & 0.160 \\
\hline Systolic BP* (mm/Hg) & $114.3 \pm 10.9$ & $111.7 \pm 10.5$ & $115.1 \pm 10.9$ & 0.100 \\
\hline Diastolic BP* (mm/Hg) & $75.7 \pm 7.1$ & $75.2 \pm 7.3$ & $75.9 \pm 7.1$ & 0.388 \\
\hline
\end{tabular}

*(BP: Blood Pressure) 
Table 2. Comparison of the laboratory findings in obese and overweight individuals

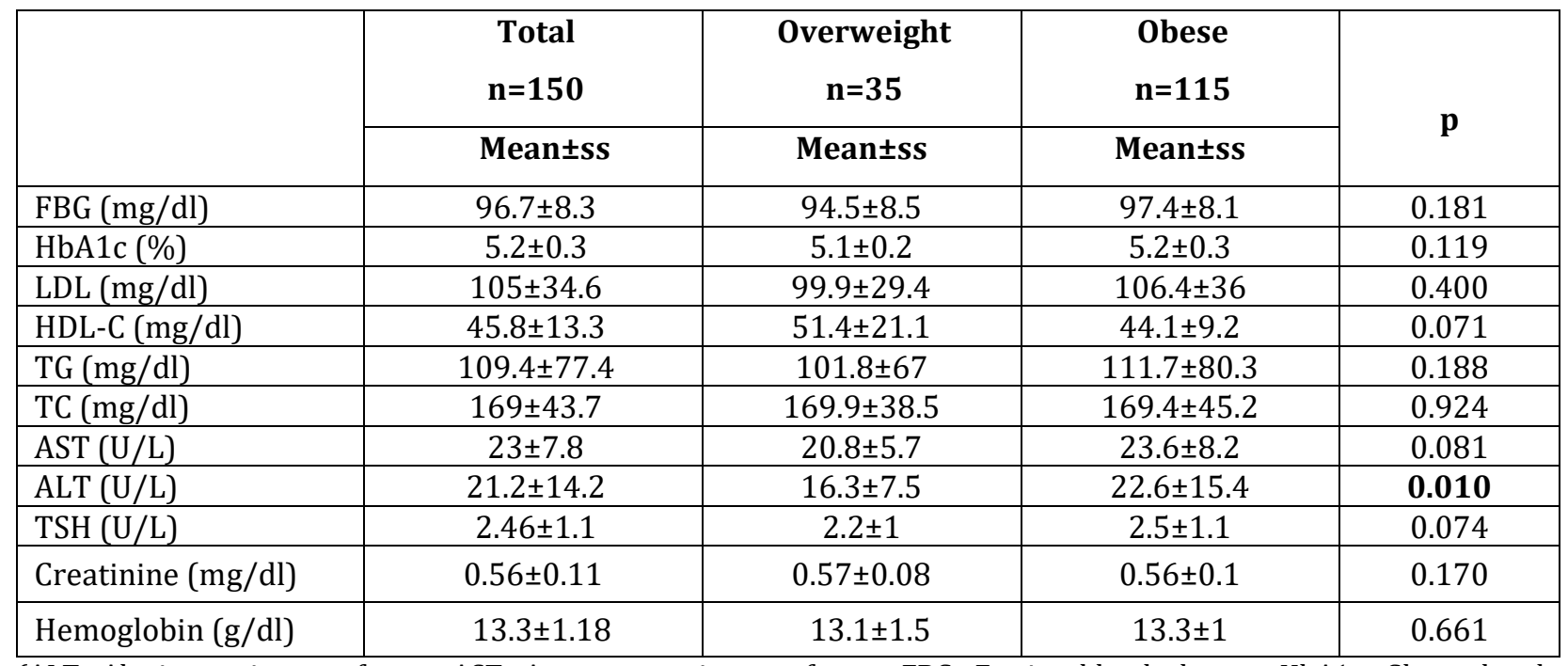

(ALT: Alanine aminotransferase, AST: Aspartate aminotransferase, FBG: Fasting blood glucose, HbA1c: Glycosylated hemoglobin, HDL: High-density lipoprotein, LDL: Low-density lipoprotein, TC: Total cholesterol, TG: Triglyceride, TSH: Thyroid-stimulating hormone)

Table 3. Presence of metabolic syndrome and its relationship with anthropometric measurements

\begin{tabular}{|c|c|c|c|c|c|}
\hline & \multicolumn{2}{|c|}{$\begin{array}{c}\text { MetS positive } \\
n=33 \\
\end{array}$} & \multicolumn{2}{|c|}{$\begin{array}{c}\text { MetS negative } \\
n=117\end{array}$} & \multirow{2}{*}{$\mathbf{p}$} \\
\hline & Mean \pm ss & $\begin{array}{c}\text { Median } \\
\text { (Min-Max) }\end{array}$ & Mean \pm ss & Median (Min-Max) & \\
\hline Age & $14.2 \pm 2.16$ & $13(11-18)$ & $13.6 \pm 2.15$ & $13(11-18)$ & 0.171 \\
\hline Height $(\mathrm{cm})$ & $163.3 \pm 11.45$ & $161(138-188)$ & $159 \pm 10.1$ & $160(134-190)$ & 0.184 \\
\hline Weight (kg) & $77.7 \pm 16.6$ & $75(50-130)$ & $70.9 \pm 14.6$ & $70(45-126)$ & 0.036 \\
\hline BMI $\left(\mathrm{kg} / \mathrm{m}^{2}\right)$ & $28.7 \pm 3.4$ & $29.1(21,9-38)$ & $27.4 \pm 3.5$ & $26.9(20.5-39.2)$ & 0.040 \\
\hline Waist circumference $(\mathrm{cm})$ & $96 \pm 10.2$ & $95(76-121)$ & $90.3 \pm 8.7$ & $88(72-117)$ & 0.003 \\
\hline Hip circumference $(\mathrm{cm})$ & $108.4 \pm 9.6$ & $109(89-133)$ & $103 \pm 8.9$ & $102(86-126)$ & 0.014 \\
\hline Waist-to-hip ratio & $0.87 \pm 0.05$ & $0.9(0.75-0.98)$ & $0.86 \pm 0.05$ & $0.87(0.71-1.03)$ & 0.186 \\
\hline Systolic BP* (mm/Hg) & $119 \pm 13.7$ & $120(90-150)$ & $113 \pm 9.6$ & $110(90-145)$ & 0.012 \\
\hline Diastolic BP* (mm/Hg) & $77.8 \pm 8$ & $80(60-95)$ & $75.1 \pm 6.8$ & $75(60-90)$ & 0.082 \\
\hline
\end{tabular}

*(BP: Blood Pressure, MetS: Metabolic Syndrome) 
Table 4. Relationship between the laboratory findings and CMR

\begin{tabular}{|c|c|c|c|c|c|}
\hline & \multicolumn{2}{|c|}{$\begin{array}{c}\begin{array}{c}\text { CMR positive } \\
n=33\end{array} \\
\end{array}$} & \multicolumn{2}{|c|}{$\begin{array}{c}\text { CMR negative } \\
n=117 \\
\end{array}$} & \multirow[b]{2}{*}{$\mathbf{p}$} \\
\hline & Mean \pm ss & Median (Min-Max) & Mean \pm ss & Median (Min-Max) & \\
\hline $\mathrm{FBG}(\mathrm{mg} / \mathrm{dl})$ & $97.7 \pm 8.5$ & $98.7(77-119)$ & $95.8 \pm 8.02$ & $96(64-113)$ & 0.161 \\
\hline HbA1c $(\%)$ & $5.2 \pm 0.32$ & $5.2(4.5-6.2)$ & $5.2 \pm 0.31$ & $5.2(4.2-6.5)$ & 0.469 \\
\hline LDL (mg/dl) & $104.4 \pm 33.8$ & $104(52-256)$ & $105.4 \pm 35.4$ & $103(43.4-277)$ & 0.801 \\
\hline HDL-C (mg/dl) & $42.2 \pm 7.9$ & $41(25-62)$ & $48.9 \pm 16$ & $46.5(21-145)$ & 0.001 \\
\hline $\mathrm{TG}(\mathrm{mg} / \mathrm{dl})$ & $118.9 \pm 92$ & $100.5(43-793)$ & $101.1 \pm 60.2$ & $86(23-397)$ & 0.031 \\
\hline $\mathrm{TC}(\mathrm{mg} / \mathrm{dl})$ & $164.6 \pm 43.2$ & $160(18.3-271)$ & $173.9 \pm 43.8$ & $172(87-388)$ & 0.271 \\
\hline AST (U/L) & $24.2 \pm 9.3$ & $22(12-64)$ & $21.8 \pm 5.9$ & $21(12-51)$ & 0.185 \\
\hline ALT (U/L) & $24.1 \pm 17.5$ & $17.5(8-132)$ & $18.5 \pm 9.8$ & $16(6-50)$ & 0.008 \\
\hline TSH (U/L) & $2.4 \pm 1$ & $2.14(0.76-5)$ & $2.4 \pm 1.19$ & $2(0.9-5.6)$ & 0.600 \\
\hline Creatinine (mg/dl) & $0.56 \pm 0.1$ & $0.54(0.38-0.85)$ & $0.56 \pm 0.12$ & $0.56(0.32-0.96)$ & 0.889 \\
\hline Hemoglobin (g/dl) & $13.2 \pm 1.23$ & $13.2(9.6-16.2)$ & $13.3 \pm 1.11$ & $13.4(10.3-16.1)$ & 0.435 \\
\hline
\end{tabular}

(ALT: Alanine aminotransferase, AST: Aspartate aminotransferase, FBG: Fasting blood glucose, HbA1c: Glycosylated hemoglobin, HDL: High-density lipoprotein, LDL: Low-density lipoprotein, MetS: Metabolic Syndrome, TC: Total cholesterol, TG: Triglyceride, TSH: Thyroid-stimulating hormone)

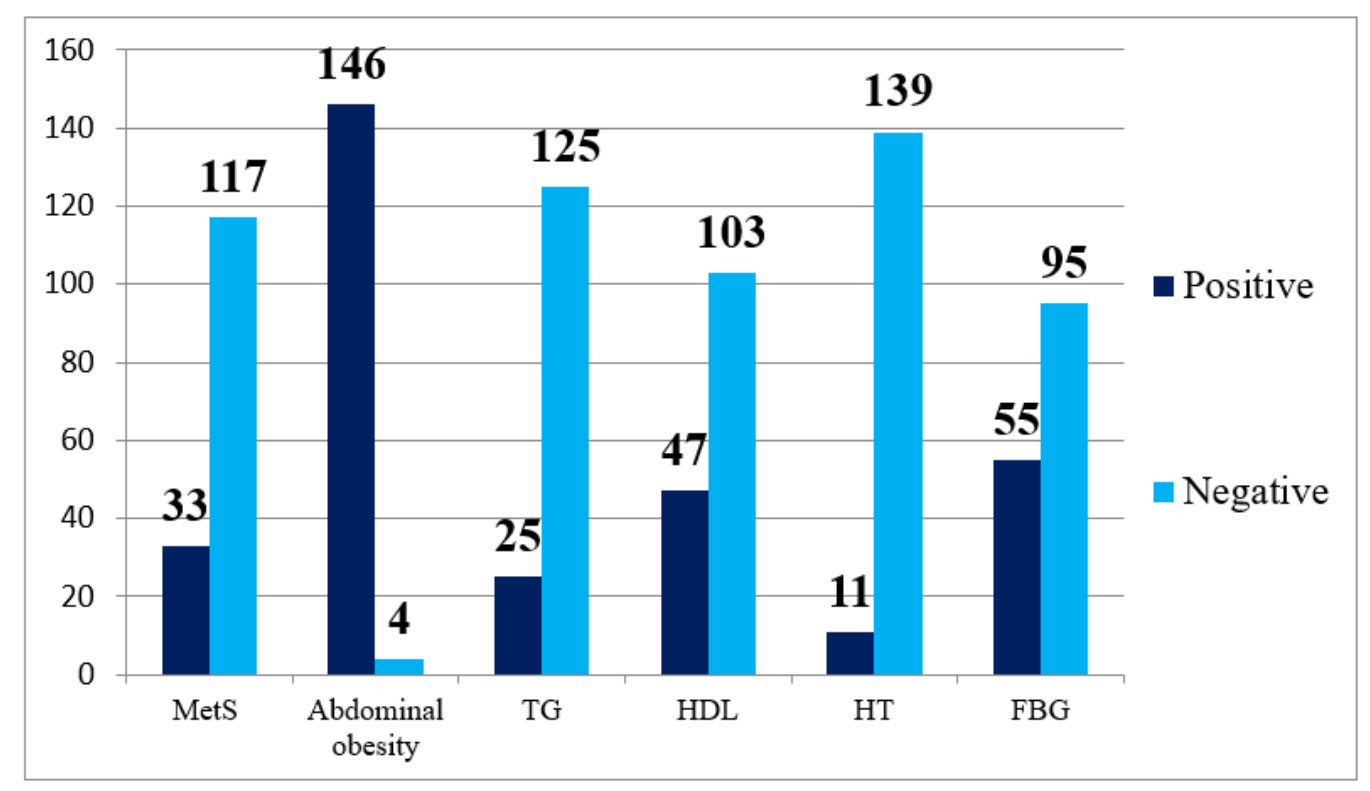

Figure 1: Distribution of metabolic syndrome and its criteria by the number of individuals (FBG: Fasting blood glucose, HDL: High-density lipoprotein, HT: Hypertension, MetS: Metabolic Syndrome, TG: Triglyceride) 


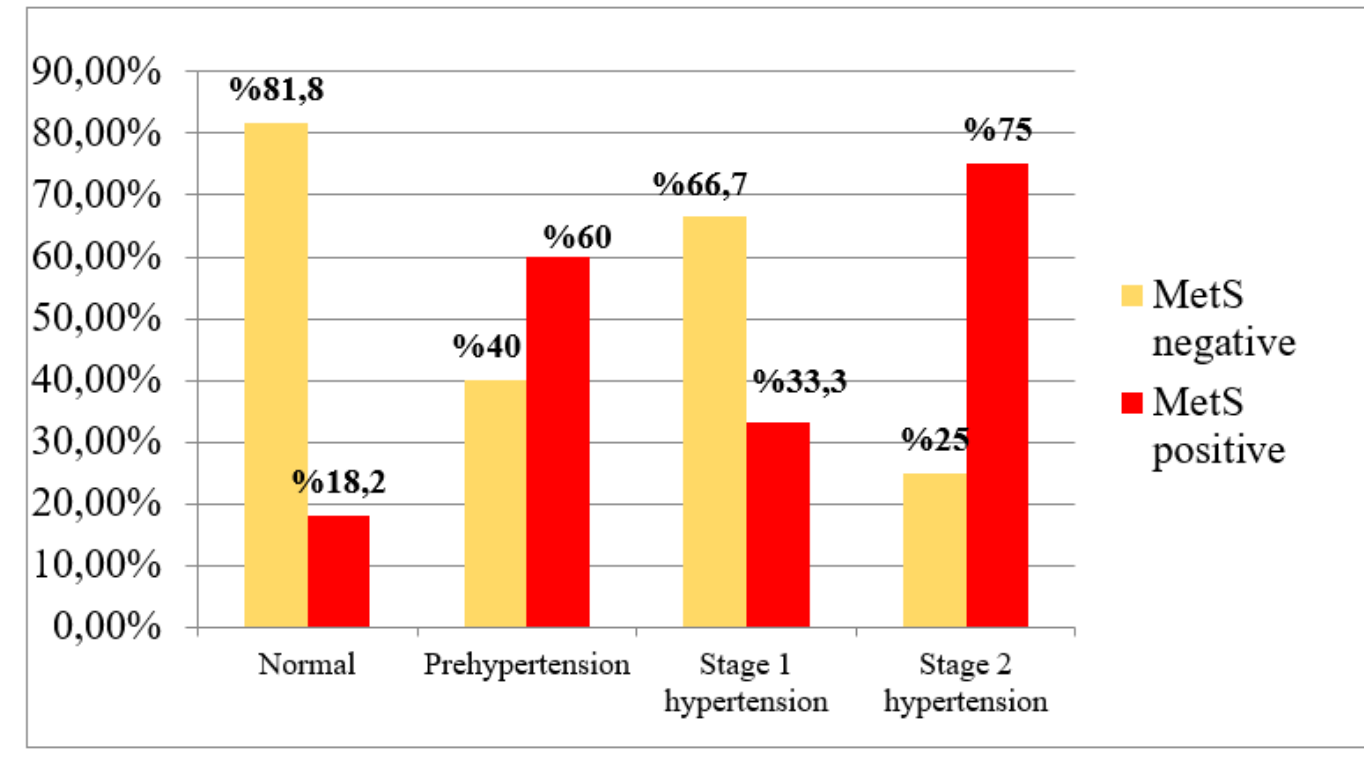

Figure 2. Blood Pressure percentile classification according to the presence of MetS

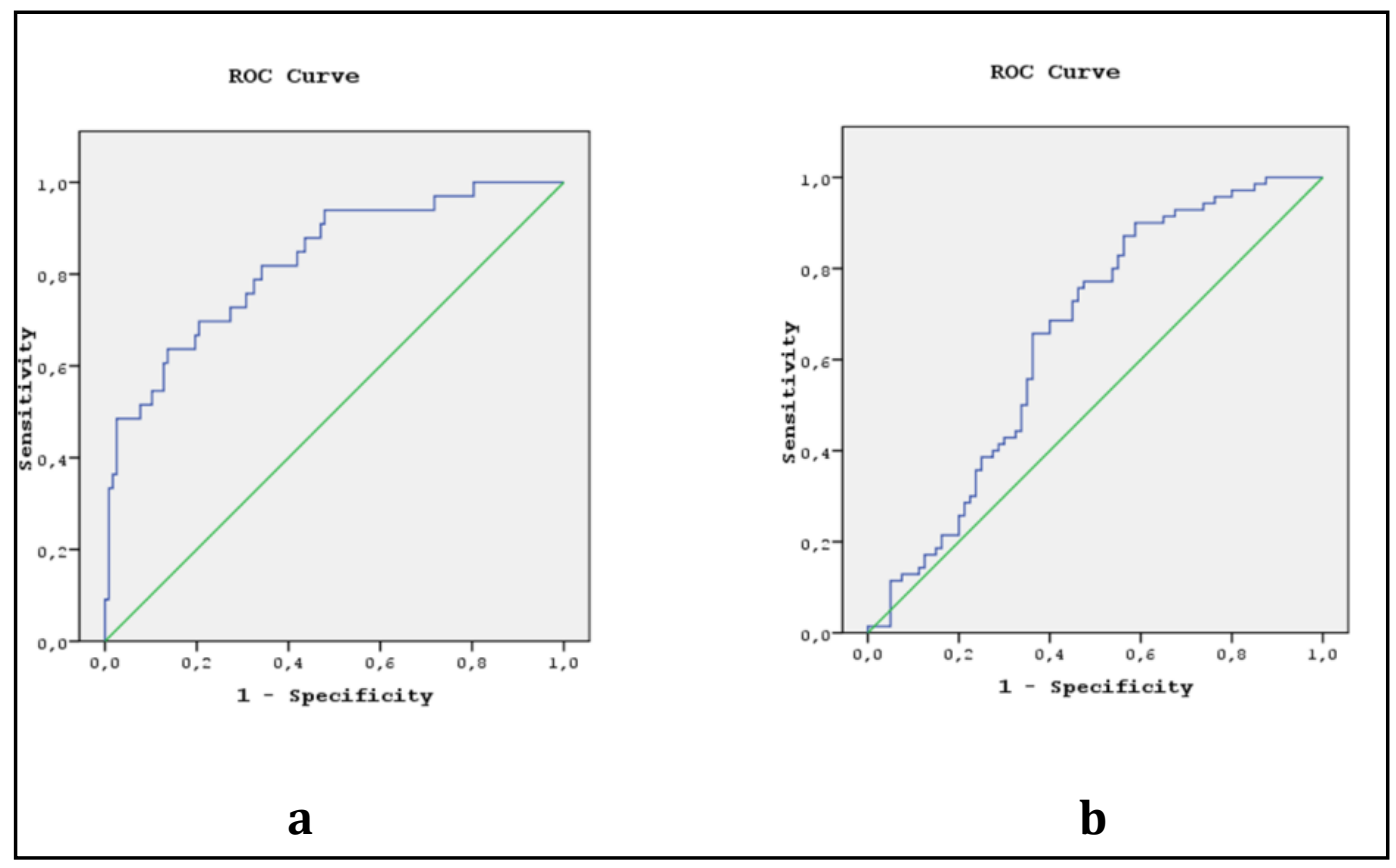

Figure 3a-b. Relationship graph of MetS, CMR, and TG/HDL (respectively)

(MetS: Metabolic Syndrome, CMR, Cardiometabolic risk, TG/ HDL: Triglyceride - high-density lipoprotein ratio) 


\section{Discussion}

The rapid increase in the prevalence of childhood obesity constitutes an important public health problem in Turkey as in many countries of the world. ${ }^{10}$ Obesity leads to the development of many obesity-related diseases such as hypertension, diabetes, metabolic syndrome, and cardiometabolic diseases. ${ }^{2-3}$ It is important to increase the awareness of clinicians about childhood obesity and obesity-related complications and also to prevent different chronic diseases that may occur with an effective intervention to obesity.

Considering the relationship between obesity prevalence and sex in previous studies conducted on children and adolescents, the prevalence of obesity was reported to be higher in males aged 13-15 years (9\%) than in females of the same age group (5\%). ${ }^{11}$ Another study reported that the prevalence of obesity was higher in males among school children aged 6-16 years. ${ }^{12}$ This may stem from the fact that female pay more attention to their body because their interest in body perception starts at a much earlier age than that observed in men. ${ }^{13}$

In this study, the prevalence of HT in overweight and obese adolescents was $8.70 \%$, and $3.30 \%$ of the adolescents were prehypertensive. This prevalence was reported to be $16.30 \%$ in a study conducted on obese children in Turkey. ${ }^{10}$ The prevalence of HT was relatively lower in our study than that reported by other studies. This may stem from the cross-sectional nature of the study and the fact that the sample was confined to a certain region as well as the inclusion of both overweight and obese subjects. In fact, the mean systolic and diastolic BP values were higher in obese but not significant in our study. Several studies have reported the presence of a correlation between elevated BP levels and obesity in the literature. A study conducted in Saudi Arabia revealed a significant relationship between increased BMI values and elevated systolic and diastolic BP in adolescents. ${ }^{14}$ According to a study conducted in Canada, the systolic BP of obese adolescents was $7.60 \mathrm{mmHg}$ higher than that of normal-weight adolescents. It was asserted that BMI had the strongest impact on BP. ${ }^{15}$ We believe that BP measurements should be performed in overweight and obese adolescents at each visit.

Similar to a study conducted in our country, our study also revealed a significant relationship between MetS and BP classification, wherein the highest prevalence of MetS was observed in subjects with stage 2 HT. ${ }^{16}$ In a review investigating the prevalence of MetS based on the IDF criteria, the prevalence of MetS in overweight and obese children ranged between $16 \%$ and $44 \%$, with no difference between males and females. ${ }^{17}$ The prevalence of MetS in obese children and adolescents in Turkey as reported by studies employing the IDF criteria was as follows: 33\%, Sangun et al.; and 30.30\%, İnanç et al.18-19 In our study, the prevalence of MetS was $22 \%$, which was lower than the values reported in these Turkish studies employing the IDF criteria possibly because of the fact that other studies included subjects within a wider age interval. 
Obese children, particularly those with increased abdominal fat, should be tested for nonalcoholic fatty liver disease (NAFLD). Studies have shown that NAFLD has become the most common liver disease in children owing to the increasing prevalence of obesity in children and adolescents. ${ }^{20}$ The prevalence of NAFLD has doubled within the last 20 years, which is strongly associated with MetS. ${ }^{21}$ The leading causes of primary NAFLD include MetS; central obesity; elevated TG, HT, and LDL; and hyperglycemia. ${ }^{22}$ In this study, there was a significant correlation between BMI classification and ALT, which was considered to be a possible indicator of fatty liver. Therefore, liver function tests should be performed for obese children and adolescents, followed by further tests if necessary, and the subjects should be monitored for potential hepatic pathologies.

In our study, $52.70 \%$ of the subjects had CMR according to the REGODCI classification. The rate of CMR was higher in males than in females like in a study. ${ }^{23}$ We believe that the male gender is a CMR factor not only in adulthood but also in childhood and that the risk tracks from childhood into adulthood. Another study has reported that the best predictors of cardiometabolic comorbidities among anthropometric parameters were BMI and waist circumference in obese pubertal adolescents like in our study. ${ }^{24}$

In this study, while the mean TG value was higher, the mean HDL value was lower in subjects with CMR. An increased TG/HDL ratio is used as an indicator of cardiovascular disease (CVD) risk in adults. ${ }^{25}$ Studies have reported that the TG/HDL ratio is associated with early-onset vascular damage in obese children and adolescents as well as in obese adults. ${ }^{26}$ In this study, the TG/HDL ratio was significant in subjects diagnosed with MetS and subjects with CMR. However, the correlation was strong only for the subjects diagnosed with MetS. Accordingly, overweight and obese children, particularly those with a TG/HDL ratio of $>2.59$, should be investigated for MetS.

Mohammed F. et al. investigated the relationship between hepatic enzymes and CMR in 3.948 students and found that the subjects with elevated ALT values had higher values of almost all the CMR factors. ${ }^{27}$ Another study investigating CMR factors, GGT, and AST/ALT ratio in with 1.084 adolescents reported that elevated GGT levels and low AST/ALT ratio were associated with CMR in both males and females; moreover, it indicated a significant difference between the subjects with and without CMR in terms of AST and ALT levels. ${ }^{28}$ We believe that liver function tests can be evaluated in addition to the CMR factors and MetS criteria starting from childhood, regardless of the anthropometric measurements.

This study reported a significant relationship between the MetS scores and the presence of CMR. MetS is accepted as a risk factor for early-onset atherosclerosis, and it causes a nearly 3-fold increased risk of CVD, which can be attributed to the effects of insulin resistance on the arteries in the cardiovascular system. ${ }^{29}$ Each MetS criterion is a risk factor for CVD development, and the presence of multiple risk factors leads to an increased risk of CVD. ${ }^{30}$ 
In conclusion, obesity is an independent risk factor for both MetS and CMR, and it should be treated immediately after diagnosis. Moreover, pre-obese adolescents should be closely monitored because they are potential obese candidates. Systolic blood pressure, TG/HDL, BMI, WC, and HC of participants were related with presenting MetS and BMI, TG/HDL, WC, HC, waist-hip ratio were related with the increase of CMR. TG/HDL ratio may use as a predictor factor for MetS (over 2.59) and for CMR (over 2.06). Furthermore, it is necessary to determine universally accepted identification systems to evaluate MetS and CMR. We believe that this would enable making a more accurate diagnosis in future studies and obtaining more accurate data about MetS and CMR in adolescents.

\section{Limitations of the study}

Obese and overweight adolescents were evaluated in the study and the absence of a comparison group consisting of normal-weight adolescents, the limited study population, and the single center of the study are the limitations of the study.

\section{Ethical approval}

The study was approved by the Clinical Research Ethics Committee at the University of Health Sciences Turkey, Şişli Hamidiye Etfal Training and Research Hospital (Date: 12.12.2017 and Approval No: 1800).

\section{Funding source}

No financial or nonfinancial benefits have been received or will be received from any party related directly or indirectly to the subject of this article.

\section{Conflict of interest for all authors}

Nothing to declare

*This study has previously been presented (as an oral presentation) in 5th International Health Science and Family Medicine Congress, 6-8 February 2020, Izmir, Turkey. 


\section{References}

1. World Health Organization, Obesity and overweight key facts [Internet] https://www.who.int/newsroom/fact-sheets/detail/obesity-and_overweight_. (Accessed: 04.04.2020).

2. Türkiye endokrinoloji ve metabolizma derneği, Metabolik sendrom kılavuzu. [Turkey endocrinology and metabolism association, Metabolic syndrome guide]. [Internet]. http://temd.org.tr/admin/uploads/tbl_yayinlar/metabolik_sendrom.pdf. (Accessed: 04.04.2020).

3. Raj M. Obesity and cardiovascular risk in children and adolescents. Indian J Endocrinol Metab 2012;16(1):13-9.

4. Kuczmarski RJ, Ogden CL, Grummer-Strawn LM, et al. CDC growth charts: United States. Adv Data 2000;314:1-27.

5. Hatipoglu N, Ozturk A, Mazicioglu M, Kurtoğlu S, Seyhan S, Lokoglu F. Waist circumference percentiles for 7 to 17 year-old Turkish children and adolescents. Eur J Pediatr 2008;167(4):383-9.

6. National High Blood Pressure Education Program Working Group on Hypertension Control in Children and Adolescents. The fourth report on the diagnosis, evaluation, and treatment of high blood pressure in children and adolescents. Pediatrics 2004;114:555-73.

7. Zimmet $\mathrm{P}_{L}$ Alberti $\mathrm{KG}_{2}$ Kaufman $\mathrm{F}_{L}$ et al. The metabolic syndrome in children and adolescents-an IDF consensus report. Pediatr Diabetes_2007;8(5):299-6.

8. Sovio U, Skow A, Falconer C, Park MH, Viner RM, Kinra S. Improving prediction algorithms for cardiometabolic risk in children and adolescents. J Obes 2013;2013:684782.

9. Tamir I, Heiss G, Glueck CJ, Christensen B, Kwiterovich P, Rifkind B. Lipid and lipoprotein distributions in white children ages 6-19 yrs: the Lipid Research Clinics Program Prevalence Study. J Chronic Dis 1981;34(1):27-39.

10. Yucel BB, Toprak D. Evaluation of anthropometric and biochemical parameters in obese children between 6-16 years. Ankara Med J 2016;16(1):27-40.

11. T.C. Sağlık Bakanlığı (TR). Türkiye obezite (şişmanlık) ile mücadele ve kontrol programı. [Struggle with obesity and control program in Turkey] Ankara: Sağlık Bakanlı̆̆ı Yayın No: 773; 2011.

12. Akac H, Babaoglu K, Hatun S, Aydogan M, Turker G, Gokalp AS. Kocaeli bölgesindeki okul çağı çocuklarında obezite ve risk faktörleri. Pediatr J 2002;2(1):29-2.

13. Guney C. Assessment of moderation effect of personality traits on the relationship between body image and social anxiety among adolescents aged between 15-18 years. Ph.D. Thesis, Isık University Institute of Social Sciences, Department of Clinical Psychology, Istanbul; 2018.

14. Al-Agha AE, Mahjoub AO. Impact of body mass index on high blood pressure among obese children in the western region of Saudi Arabia. Saudi Med J 2018;39(1):45-1. 
15. Shi Y, de Groh M, Morrison H. Increasing blood pressure and its associated factors in Canadian children and adolescents from the Canadian Health Measures Survey. BMC Public Health 2012;12(1):388-8.

16. Ozer S, Sonmezgoz E. Frequency of metabolic syndrome and its components in obese children. J of the Child 2015;15(1):10-5.

17. Friend A, Craig L, Turner S. The prevalence of metabolic syndrome in children-a systematic review. Arch Dis Child 2012;97(1):116-7.

18. Sangun O, Dundar B, Kosker M, Pirgon O, Dundar N. Prevalence of metabolic syndrome in obese children and adolescents using three different criteria and evaluation of risk factors. J Clin Res Ped Endo $2011 ; 3(2) 70-6$.

19. Inanc BB. Metabolic syndrome in school children in Mardin, South-Eastern of Turkey. Eurasian J Med 2014;46(3):156-63.

20. Marzuillo P, Miraglia del Giudice E, Santoro N. Pediatric fatty liver disease: role of ethnicity and genetics. World J Gastroenterol 2014;20:7347-55.

21. Welsh JA, Karpen S, Vos MB. Increasing prevalence of nonalcoholic fatty liver disease among United States adolescents, 1988-1994 to 2007-2010. J Pediatr 2013;162:496-500.

22. Ugras M, Kucuk O, Bicer S, Vitrinel A. Non alcoholic fatty liver disease in children. Bozok Med J 2014;4(1):55-61.

23. Jayawardene WP, Lohrmann D, Dickinson S, Talagala S, Torabi M. Clinical measures of obesity and cumulative cardiometabolic risk in adolescents. Clin Obes 2016;7(1):11-1.

24. Blüher S, Molz E, Wiegand S, et al. Adiposity patients registry initiative and the German competence net obesity. Body mass index, waist circumference, and waist-to-height ratio as predictors of cardiometabolic risk in childhood obesity depending on pubertal development. J Clin Endocrinol Metab 2013;98(8):3384-93.

25. Sogut E, Avcı E, Ustuner F, Arikan E. The evaluation of (TG/HDL-C) ratio as a serum atherogenic Index. Turk J Biochem 2006;4:1-8.

26. Giorgis T, Marcovecchio ML, Giovanni I, et al. Triglycerides-to-HDL ratio as a new marker of endothelial dysfunction in obese prepubertal children. Eur. J. Endocrinol 2014;170(2):173-80.

27. Mohammadi F, Qorbani M, Kelishadi R, et al. Association of cardiometabolic risk factors and hepatic enzymes in a national sample of Iranian children and adolescents: the CASPIAN-III study. J. Pediatr. Gastroenterol. Nutr 2014;58(4):463-8.

28. Labayen I, Ruiz JR, Ortega FB, et al. Liver enzymes and clustering cardiometabolic risk factors in European adolescents: the HELENA study. Pediatr Obes 2015;10(5):361-70.

29. Steinberger J, Daniels SR, Eckel RH, et al. Progress and challenges in metabolic syndrome in children and adolescents: a scientific statement from the American Heart Association Atherosclerosis, Hypertension, and Obesity in the Young Committee of the Council on Cardiovascular Disease in the Young; Council on 
Cardiovascular Nursing; and Council on Nutrition, Physical Activity, and Metabolism. Circulation 2009;119(4):628-47.

30. Alexander CM, Landsman PB, Teutsch SM, Haffner SM. NCEP-defined metabolic syndrome, diabetes, and prevalence of coronary heart disease among NHANES III participants age 50 years and older. Diabetes 2003;52(5):1210-4. 